\title{
Implementation of the HOT FIT Model in the Evaluation of Education and Learning During the Pandemic Covid-19
}

\author{
Yulita Triadiarti $^{1, *}$, Taufik Hidayat ${ }^{1}$, La Ane $^{1}$, Choms Gary G.T Sibarani ${ }^{1}$ \\ ${ }^{I}$ Department of Accounting, Faculty of Economics, Universitas Negeri Medan \\ *Corresponding Author.Email: yulita@unimed.ac.id
}

\begin{abstract}
This study aims to develop HOT FIT Model; this model is very suitable for evaluating E-Learning, namely the distance learning method used during a pandemic. The HOT Fit model is used in technology and information-based systems, which are needed during this Pandemic. This study using method of three factors are related to the seven dimensions of information system success, namely Quality Systems, Information Quality, Service Quality, System Use, User Satisfaction, and Net Benefit. And the result of this research is the E-Learning system is used to support the learning process during the Covid-19 Pandemic. In the implementation of the e-learning system, efforts are made to improve the quality of education. E-Learning requires evaluation to measure the feasibility level, even the success of the E-Learning performance itself. An evaluation must be done because the evaluation will assess or measure the benefits obtained from its application. One evaluation model used in education and teaching is the HOT (Human, Organization, Technology) Fit evaluation model. This model involves three main factors, namely User, Organization, and technology, which are supported by the critical variables of the success of the information system consisting of System Quality, Information Quality, Service Quality, and System Use system), User Satisfaction (user satisfaction), and Net Benefit (system benefits). The research that has been done is testing how the Hot Fit model is implemented in higher education. In this case, the Hot Fit Model is natural to be implemented in Basic Education, considering that in the implementation of distance learning during the Pandemic, almost all teaching and learning activities will intersect with technology that will automatically.
\end{abstract}

Keywords: HOT Fit Model, Pandemic Covid-19, Higher Education

\section{INTRODUCTION}

The Covid-19 Pandemic has had a considerable impact on the education sector. All schools and colleges in countries affected by the Covid-19 Pandemic have implemented a home learning policy or Distance Learning. There are many challenges faced by teachers, learners, institutions, and even the broader community as parents in implementing this distance learning. Teachers must find and prepare various ways to convey and receive learning material well by learners. Likewise, learners require more significant effort, both in material, energy, and psychological readiness. This is done so that learners can receive learning material optimally [1].

Distance learning is a learning system that does not occur in one room, and there is no face-to-face interaction between teachers and learners [2]. In an era of the rapid development of technology, communication, and information, distance learning during this Pandemic can be carried out using various platforms, both in learning management systems and video conferencing. Learning management systems used include google classrooms and E-learning portals owned by schools or colleges. Meanwhile, video conferencing applications widely used during distance learning include the zoom application, google meet, and Cisco WebEx. Apart from these applications, WhatsApp Group is also an alternative in implementing distance learning. During the implementation of distance learning during the Covid-19 Pandemic, the challenges and obstacles were limited to the limited technical support facilities and internet networks. Other obstacles to implementing distance learnings during the Covid-19 Pandemic include the readiness of human resources, unclear government directions, and the absence of a proper distance learning curriculum [3]. The readiness of human resources is an 
essential part of the successful implementation of distance learning; this readiness is related to teachers' and learners' ability to use and manage all technological systems used in the distance learning process.

The Ministry of Education and Culture [4] issued Circular Letter Number 15 of 2020 concerning Guidelines for Organizing Learning from Home in an Emergency for the Spread of Covid-19. Based on Circular Number 15, which is strengthens the Ministry of Education and Culture Number 4 of 2020 concerning on the Implementation of Education in the Emergency Period of Coronavirus Disease (Covid-19). In this circular, it is stated that the purpose of implementing Learning From Home (LFH) is to ensure the fulfilment of students' rights to get educational services during the Covid-19 emergency, protect education unit residents from the adverse effects of Covid-19, prevent the spread and transmission of Covid-19 in education unit and ensure the fulfilment of psychosocial support for educators, students, and parents. LFH activities are carried out to provide meaningful learning experiences for students without being burdened with demands to complete all curriculum achievements and focus on life skills education, including the Covid-19 Pandemic. Learning material must be under the age and level of education, cultural context, character, and specificity of students. LFH activities and assignments may vary between regions, academic units, and students according to their respective interests and conditions, including considering gaps in access to Learning facilities. During LFH, student learning outcomes are given qualitative and useful feedback from the teacher without being required to give quantitative scores/scores and promote positive interaction and communication patterns between teachers and parents [5].

Some components include the main components in the learning design, namely, objectives, materials, strategies, media, and evaluation. A goal is something you want to achieve. The material is material that students learn or teach teachers to students; strategies are the steps taken by students and/or teachers in learning (teacher $=$ teaching) subject matter to achieve goals. The media is a means to facilitate the achievement of goals, and evaluation is a process to determine learning outcomes and effectiveness. Thus, evaluation is one of the main components that are always there in learning. In other words, learning cannot be separated from evaluation activities [6].

In general, evaluation has two main functions, namely, to determine the achievement of student learning outcomes and teacher teaching outcomes. Knowledge of student learning outcomes is related to how students have achieved the learning objectives or the specified competencies. Teacher teaching outcomes are related to the extent to which the teacher is a manager in planning, managing, leading, and evaluating. The reality shows that there are still many who reduce evaluation as a test activity. This is evidenced by prominent evaluation activities in institutions and academic units. This activity is the implementation of tests that are carried out after completing certain subjects (specific essential competencies) as formative tests and final semester tests known as summative tests and tests held at the end of certain education levels in the form of school final exams and national exams. The coverage of educational objectives, both at the national level, level of education, academic units, even up to subject objectives (subject competency standards) contain cognitive, affective, and psychomotor domains, so it is ironic if the learning process is long ( 3 to 6 years), sometimes determined by the results of a written test conducted over several hours in a particular subject. In this paper, we will briefly describe the evaluation model of Distance Learning in Basic Education to determine the achievement of student learning outcomes and the effectiveness of the learning process.

The evaluation model plan that will be discussed in this paper is the Hot Fit Evaluation Model. This model is very suitable for evaluating E-Learning, namely the distance learning method used during a pandemic. The HOT Fit model is used in technology and informationbased systems, which are needed during this Pandemic. This model actually can not only be used in the evaluation of learning but can also be used in evaluating the implementation of other online-based application systems (in-network) [7].

\section{LITERATURE REVIEW}

\subsection{Evaluation of the Implementation of Distance Learning in Basic Education Using the Hot Fit Model.}

Many models can be used to evaluate education and learning in Primary Education during the Pandemic. Based on the references obtained during the Pandemic, the most relevant evaluation model is the evaluation model related to distance learning. The distance learning model can be done through e-learning, or the term is online, offline, and Blended Learning, which combines online and offline learning.

E-Learning is an independent learning process that is facilitated and supported through information and communication technology. The E-Learning model itself can generally be divided into two major categories: Static E-Learning and Dynamic E-Learning. The most important thing needed in building an E-Learning is the interaction between the user and the computer.

E-Learning has the following philosophy:

1. E-Learning is the delivery of information communication, education, online training.

2. E-Learning provides a set of tools that can enrich the value of conventional learning so that it can answer the challenges of globalization

3. E-Learning does not replace conventional learning models in the classroom but reinforces 
it through content enrichment and educational technology development.

4. Students' capacity varies greatly depending on the form of the content and the way it is conveyed. The better the alignment of content and delivery tools with learning styles, the better the student's capacity, which in turn will give better results.

\subsection{Hot (Human, Organization, Technology) Fit Model}

This model was proposed by [8]. The rationale for this model comes from the information system evaluation model of [9]. This evaluation model clarifies all the components contained in the information system itself, namely:

1. Humans (humans) who assess the information system from the side of use (system use) relate to those who use training, experience, knowledge, expectations, and attitudes to accept and reject the system.

2. Organization (Organization) assesses a system from the organizational structure and organizational environment related to planning, management, system control, management support, and financing.

3. Technology (Technology), which assesses the quality of the system, the quality of information, and the quality of service.

The HOT Fit framework includes:

1. Organizational Factors.

2. The suitability factor between humans, organizations, and technology.

3. Two-way relationship between the following dimensions: information quality and system use, information quality, and user satisfaction.

These three factors are related to the seven dimensions of information system success, namely Quality Systems, Information Quality, Service Quality, System Use, User Satisfaction, and Net Benefit.

These dimensions affect one another as follows:

a. System Quality, Information Quality, Service Quality together tend to influence System Use and User Satisfaction.

b. System Use and Information Quality can influence each other or have a reciprocal relationship with each other.

c. System Use and User Satisfaction can affect the degree of User Satisfaction. System Use and User Satisfaction directly influence and have a reciprocal relationship to Net Benefit.

\section{RESULT AND DISCUSSION}

The research that has been done is testing how the Hot Fit model is implemented in higher education. In this case, the Hot Fit Model is natural to be implemented in Basic Education, considering that in the implementation of distance learning during the Pandemic, almost all teaching and learning activities will intersect with technology that will automatically force users' cases, learners. And the schools for literacy technology

A new framework that can be used to evaluate information systems called the Human-Organization Technology (HOT) Fit Framework. "This Framework builds on the IS Success Model and IT-Organization Fit Model. HOT-fit addresses of essential components of IS, namely human, organization and technology and the fit between them" [8]. This model places an essential component in the information system, namely Human, Organization, and Technology, and the suitability of the relationship between them. The HOT-Fit Framework was initially developed from the combination of the IS Success Model and the IT Organization Fit Model proposed by as a framework for evaluating the Health Information System (HIS). The IS Success Model identifies factors, dimensions, and measurement indicators, while the IT-Organization Fit Model identifies the relationship and conceptual suitability between human, technology, and organizational factors. This model in the research of [10] is used to measure the application of information systems in the public sector, namely measuring the success of the Malaysian Government's e-government called the Project Monitoring System (PMS). Argued that human, technology, and organizational factors are essential components in applying information systems, where the system's impact is evaluated through overall net benefits.

In the Figure, it can be seen that the HOT-Fit Framework consists of several reciprocal relationships, as explained by [8] as follows:

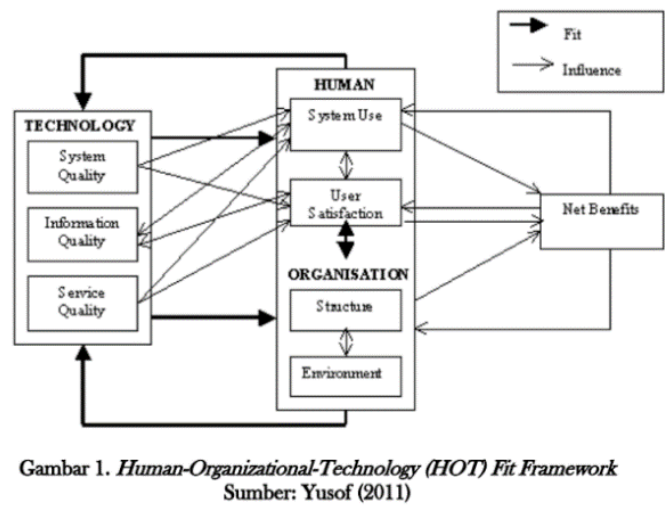

Figure 1. HOT Fit Framework

"Some of these relationships are two ways: .... System Use and User Satisfaction are direct antecedents of Net Benefits. Net Benefits subsequently affect System Use and User Satisfaction. Similar, Organizational Structure and Environment are direct antecedents of Net Benefits. 
Net Benefits subsequently have an impact on organizational Structure and Environment " [11].

According to [8], the factors that make up the HOTFit Framework are as follows:

1. Human.

The human component assesses the information system in terms of system use on the frequency and breadth of information systems' functions and investigations. System use also relates to who uses (who use it), the level of users (level of user), training, knowledge, expectations, and attitudes to accept or reject the system. This component also assesses the system from user satisfaction, namely the overall evaluation of user experience in using information systems and the potential impact felt from using information systems. User satisfaction can be related to perceived benefits and user attitudes towards information systems influenced by personal characteristics.

\section{Organization.}

The Organization component (organization) assesses the system from the aspects of the organizational structure and the organizational environment in which the information technology system is implemented. The organizational structure consists of a type, culture, politics, hierarchy, planning, and control of systems, strategy, management, and communication. Leadership, support from top management, and staff support are an essential part of measuring the system's success. Meanwhile, the organizational environment consists of funding sources, governance, politics, competition, interorganizational relations, and communication.

3. Technology

\section{a. System Quality}

This factor is used to measure the quality of the information technology system itself. Some of the indicators that [8] to measure the value of system quality are as follows: - ease indicators, which include: easy to use (ease of use) and easy to learn (ease of learning), - efficiency indicators which include: response time and loading time, system reliability indicators which include: system technical assistance (access to technical support), error warning, flexibility if integrated with other systems (availability), tested to be free from errors (reliability) and system security (security), - indicators completeness includes: exclusive features and complete database contents.

\section{b. Information Quality (Output)}

This factor is used to measure the quality of the information system's output (output). Some of the indicators to measure the value of the quality of output information are as follows:
- Content indicators which include: format according to needs, form and relevance of the information generated, completeness,

- Indicators of usefulness which include: easily readable, concise and concise, informative, significant,

- Level of data reliability: data accuracy, timeliness, comparability, and verifiability.

\section{c. Quality of Service}

This factor focuses on the overall support received from the system service provider. Service quality can be assessed by the speed of response, assurance, empathy, technical support, and follow-up service to system users. Net benefits can be measured directly from the system benefits (for example, from the information generated by the system) and indirect benefits such as the impact on performance, efficiency, and effectiveness of organizational activities.

The picture above describes the relationship between the Hot Fit Model's main components, namely the Human, Organization, and Technology, along with each component's main points. Excellence in human and organizational capabilities is strongly influenced by technology, which is the primary tool for achieving benefits (success). Sound quality systems, information, and technology services will affect humans and organizations' ability to achieve goals. Furthermore, as a follow-up to humans and organizations' success, the success of achieving goals will also affect human and organizational capabilities.

\section{CONCLUSION}

The E-Learning system is used to support the learning process during the Covid-19 Pandemic. In the implementation of the e-learning system, efforts are made to improve the quality of education. E-Learning requires evaluation to measure the feasibility level, even the success of the E-Learning performance itself. An evaluation must be done because the evaluation will assess or measure the benefits obtained from its application. One evaluation model used in education and teaching is the HOT (Human, Organization, Technology) Fit evaluation model. This model involves three main factors, namely User, Organization, and technology, which are supported by the critical variables of the success of the information system consisting of System Quality, Information Quality, Service Quality, and System Use system), User Satisfaction (user satisfaction), and Net Benefit (system benefits). The research that has been done is testing how the Hot Fit model is implemented in higher education. In this case, the Hot Fit Model is natural to be implemented in Basic Education, considering that in the implementation of distance learning during the Pandemic, almost all 
teaching and learning activities will intersect with technology that will automatically.

\section{AUTHORS' CONTRIBUTIONS}

The Author of this research was contributed to support for fighting pandemic covid-19 by diversified learning process and varied with HOT model and its derivation.

\section{ACKNOWLEDGMENTS}

This Research was funded by Universitas Negeri Medan from PNBP Basic Research Program in 2020.

\section{REFERENCES}

[1] N. D. Khoeriah, "Pengembangan Model Evaluasi Kinerja Sd Penyelenggara Pendidikan Inklusif," Jurnal Penelitian dan Evaluasi Pendidik., vol. 17, no. 1, 2013, doi: 10.21831/pep.v17i1.1360.

[2] Abdul Latip, "Peran Literasi Teknologi Informasi Dan Komunikasi Pada Pembelajaran Jarak Jauh Di Masa Pandemi Covid-19," EduTeach Jurnal Edukasi dan Teknologi.. Pembelajaran, vol. 1, no. 2, 2020, doi: 10.37859/eduteach.v1i2.1956.

[3] A. Koesnandar, "Pengembangan Inovasi Pembelajaran Berbasis Tik Pada Sekolah Di Daerah 3t Papua Dan Papua Barat Melalui Pendampingan Jarak Jauh," Kwangsan Jurnal Teknologi Pendidikan., vol. 6, no. 2, 2018, p177--198. doi: 10.31800/jtp.kw.v6n2.

[4] Kemendikbud RI, "Surat Edaran Menteri Pendidikan dan Kebudayaan Nomor 4 Tahun 2020 Tentang Pelaksanaan Kebijakan Pendidikan dalam Masa Darurat Penyebaran Coronavirus Disease (COVID-19)," hukumonline.com, 2020. .

[5] pengelola web Kemdikbud, "Kemendikbud Terbitkan Pedoman Penyelenggaraan Belajar dari Rumah,” Jakarta, 28 Mei 2020. 2020.

[6] I. W. Gunartha, B. Kartowagiran, and S. P. Suardiman, "Pengembangan Model Evaluasi Program Layanan Pendidikan Anak Usia Dini (Paud)," Jurnal Peneliian dan Evaluasi Pendidik., vol. 18, no. 1, 2014, doi: 10.21831/pep.v18i1.2122.

[7] D. Mulyadi and A. Choliq, "Penerapan Metode Human Organization Technology (HOT-Fit Model) untuk Evaluasi Implementasi Aplikasi Sistem Informasi Persediaan (SIDIA) di Lingkungan Pemerintah Kota Bogor," Teknois Jurnal Ilmu Teknologi Informasi dan Sains, vol. 7, no. 2, 2019, doi: 10.36350/jbs.v7i2.23.

[8] M. M. Yusof, R. J. Paul, and L. K. Stergioulas, "Towards a framework for health information systems," in Proceedings of the Annual Hawaii International Conference on System Sciences, vol. 5, 2006. doi: 10.1109/HICSS.2006.491.

[9] I. Putu Ramayasa, "Evaluation model of success and acceptance of e-learning," Journal Theory
Application Information Technology, vol. 82, no. 3 , 2015.

[10] M. Yusuf and Y. Indrianti, "Inclusive Education Management Model To Improve Principal and Teacher Performance in Primary Schools," Proceeding 2nd Int. Conf. Arts Lang. Cult., 2017.

[11] M. Mirabolghasemi, S. H. Choshaly, and N. A. Iahad, "Using the HOT-fit model to predict the determinants of E-learning readiness in higher education: a developing Country's perspective," Education Information Technology, vol. 24, no. 6 , 2019, doi: 10.1007/s10639-019-09945-9. 